\title{
BIOCHEMICAL AND ENGINEERING ASPECTS OF SANITARY WATER SUPPLY.*
}

\author{
BY \\ GEORGE W. FULLER, C.E., \\ Consulting Hydraulic and Sanitary Engineer, New York, N. Y. \\ Member of the Institute.
}

THIs topic is a very broad one. In fact, some difficulty has been experienced in reaching a conclusion as to which particular aspects of this topic these remarks should be directed.

"Biochemical" is not a very precise term. It is used differently by different persons. It is proposed to-night to speak more particularly of the biological rather than the chemical phases of this broad field which deals with the sanitary features of public water supplies. Reference will be made especially to means of measuring the sanitary quality of water supply through biological methods, and then of the accomplishments upon the public health of modern engineering works to conserve or improve the quality of water. The engineering works themselves will be scarcely touched upon.

While the main theme of this talk will be means of measuring the sanitary quality of public water supplies, both through laboratory procedures and the study of vital statistics, attention will be directed to some striking instances where it is proved that public water supplies are not wholly to blame for the prevalence of diseases generally associated with the public water supply. Other sanitary conditions are involved, and, as our knowledge of vital statistics and of modes of transmission of disease becomes more complete, it is shown that the city sanitarians have duties to attend to which in earlier years were assumed to belong to those who had charge of public water supplies.

This is a particularly apt time at which to speak on this subject. During the past week the United States Treasury De-

* Based on a paper presented at the meeting of the Mechanical and Engineering Section held November I2, I9I4. Manuscript received March 24, I9I 5 . 
partment has published a report of a Commission of Expert Sanitarians to specify bacteriological standards for drinking waters to be supplied to the public by common carriers in interstate commerce. That this task has not been an easy one is shown by the fact that it has required nearly two years of deliberations to formulate a six- or seven-page report.

Another feature of importance in the current developments of sanitary science on this side of the Atlantic is the work now being done'by the International Joint Commission having control of the pollution of the boundary waters between this country and Canada. This has brought squarely to an issue the proposition of what is a reasonable load as regards pollution that modern water filters may be expected properly to carry. In populated regions surface waters of virgin purity are impossible. This does not mean, however, that pollution can not and should not be controlled within limits that will not prove overburdensome to those whose task it is to build and operate filters and other devices for the purification of public water supplies.

The Rivers Pollution Act of Great Britain, adopted in 1876 , was so stringent that it had but comparatively little influence upon the public health, owing to the difficulty and great expense involved in adjusting to it. The Royal Commission on Sewage Disposal of Great Britain decided two years ago, after deliberating for more than a dozen years, that less stringent standards should be set up and that, furthermore, plans for completed works necessary for certain conditions might derive the benefit of "relaxation." By this is meant that local authorities in Great Britain are to-day not obliged, in many cases, to build complete sewage purification works, although plans are to be prepared with that ultimate end in view, and that the construction work to that end must proceed in pursuance of local conditions both as to availability of funds for such work and as to local sanitary needs.

Laboratory methods for measuring the sanitary quality of water date back more than thirty years. They are contemporaneous in point of dates with the formulation and general recognition of the germ theory of disease and the transmission by water carriage of a number of the well-known diseases, particularly those of the intestinal group. Laboratory data do not afford a particularly satisfactory means of measuring the 
quality of water. They are simply a rough indicator, and the interpretation of the data seems to be positive and satisfactory only when they apply to a very good water or a very bad water. In the middle courses of the range of quality of water, laboratory data are to-day in need of further careful study, both as to methods in use and the interpretation of the results.

Following the Spanish-American war the sanitary world was shocked at the discovery of the extent to which disease was transmitted through the agency of flies and other insects. Those experiences were attained largely in the big army camps where the hygienic environment related more particularly to the conditions prevailing in rural rather than in urban communities. Gradually there has been determined the important fact that public water supplies are not in all cases responsible for the transmission of intestinal diseases to the extent which was hitherto thought to be the case. The recent evidence has been obtained for the most part in southern cities where the fly period is of longer duration than in the northern cities. In the latter, however, the fly period for quite a number of months each year has been a factor involving the public health to a degree much greater than has been recognized by the majority of sanitarians.

Some of the more important recent data will be shown with the aid of lantern slides to illustrate specifically these general remarks as to the need of more precise methods in the laboratory for the measurement of the sanitary quality of public water supplies; and, again, as to means of measurement of the effect of the public water supply upon the general health of the community through recognition of the influence of other aspects of municipal sanitation in bringing about high death-rates from so-called water-borne diseases, and in cases where the public water supplies are in no way at fault.

\section{DETERMINATION OF SPECIFIC PATHOGENIC BACTERIA.}

Infectious diseases, such as may be water-borne, require the presence in the water of an appreciable number of the particular pathogenic bacteria producing the disease. It follows very simply, as an academic proposition, that if a correct examination of the water can show that no such disease germs are present, the water is safe for domestic consumption, and is what is generally termed "a wholesome water." Unfortunately, such 
direct determination can be made only with the greatest of difficulty, and the results of such correct determination have only a doubtful value. A certain number of the bacteria producing water-borne diseases, such as the typhoid bacillus and the cholera spirillum, have been successfully isolated and can occasionally be detected in a polluted water. Broadly speaking, however, it is not at all certain that such bacteria will be detected, even if they are present in a public water supply.

A few investigators, among whom may be particularly mentioned Dr. A. C. Houston, Director of Water Examinations, Metropolitan Water Board, London, have insisted that their methods of determination of these specific organisms are sufficiently accurate and reliable, so that tests made by them showing that these bacteria are not present are conclusive to them that there is no danger of such diseases being caused by the water. Most of the laboratory workers do not concur in this viewpoint. They assert that, while specific bacteria may often be isolated and shown to be present in the water, they are not at all willing to say, on the other hand, that the fact that they are unable to isolate this organism shows conclusively that they are not present. They believe that the methods used are sufficiently uncertain so that typhoid or cholera bacteria may be present and still not be detected.

There is one other important factor which must be considered. We do not know with exact certainty what diseases are disseminated by water. A certain number certainly can be attributed at times to a water supply. Others are uncertain. There may be still others which may be carried by water, but we are not fully aware that they can be so carried. To make satisfactory tests of a water supply, therefore, by the direct method, would require specific tests for each particular type of pathogenic bacteria which we know can be carried by water or which possibly might be carried by water. Quite apart from the accuracy and desirability of results of such methods, the work would probably become so laborious and time-consuming for practical use in ordinary water determinations that the method falls of itself as too unwieldy to be used.

In effect, any such direct methods, ideal as they may be, fail us in service, and we must have recourse to some indirect 
method which will give us better service. The indirect methods available are, first, the determination of the total number of bacteria present in a given volume of the water, and, second, the determination of the absence or quantitative presence of certain specific bacteria which may be called indicators of the possibility of the presence of disease germs.

SIGNIFICANCE OF TOTAL BACTERIAL COUNT.

The oldest and simplest biological method of gauging the quality of a water supply is by counting the total number of bacteria by means of the colonies formed by growth on some solid nutrient medium. The method formerly used and still in most general practice is to count the total number of colonies produced by incubation on solid gelatine in forty-eight hours at a temperature of $20^{\circ}$ Centigrade, and to call this the number of bacteria present in the quantity of water examined (one cubic centimetre). By this standard, German sanitarians about twenty-five years ago fixed on one hundred bacteria per cubic centimetre as the fair dividing line between a good and an unsatisfactory water, under their local conditions as studied. Any water showing less than these one hundred bacteria per cubic centimetre was considered satisfactory, but a bacterial count in excess of this amount showed a water of inferior quality. This standard has been very much used and until fairly recent times has been considered a reasonable and proper standard for some classes of water.

A number of rather obvious objections present themselves to the use of this standard for determining the water quality. The first natural objection is that there may be, and probably is, no definite relationship between the number of bacteria present in the water and the number of pathogenic bacteria which may cause disease. The bacteria in the water originate from any number of points. They come from the soil, the vegetation, and from animals; they grow in the water itself, and many forms multiply very rapidly in the water. A pure water may show very high bacterial results, and a polluted water a relatively small bacterial count.

In considering any new source of water without knowing its special local conditions, it is almost impossible to say from 
the total bacterial count alone whether the water is good or poor or something intermediate. It even happens that in carefully filtering water the filtered effluent may show as many as, or even more bacteria than, the water applied to the filters. This comes from the fact that certain species of bacteria may grow in the filter itself, particularly in its underdrains, and from this growth of water bacteria, always of a harmless form, the effluent obtains its large bacterial count. And yet this filtered effluent may be entirely free of any pathogenic forms.

Another factor militating against the useful purpose of this total bacterial count test is that the incubation was effected at a temperature of $20^{\circ}$ Centigrade, about normal room temperature. Under such conditions the growth of the harmless water bacteria is facilitated, while the growth of the pathogenic bacteria, which naturally thrive at the body temperature, is partially inhibited. It has been attempted to meet this difficulty by specifying a different total bacterial count method of testing. This involves the incubation of the sample at a temperature of $37^{\circ}$ Centigrade, using nutrient agar as the medium. The use of the high temperature, approximately that of the body, serves the purpose of encouraging the growth of various bacteria which thrive at the body temperature, and of inhibiting the growth of the ordinary non-pathogenic bacteria. This gives relatively small counts on the plate, but these bacteria, of smaller number, perhaps, may be a fairer measure of the possible presence of contaminating organisms.

Table I of "Comparison of Gelatine and Agar Counts for Various Coli Conditions" exhibits, opposite to each other, the bacterial counts per cubic centimetre obtained by the two methods above cited. It will be seen that the bacteria shown by the $37^{\circ}$ agar test are very much lower than those shown by the $20^{\circ}$ gelatine test. There is, however, no constant relation between the two. In some cases the agar may show only ten per cent. of the bacteria of the gelatine test. In other cases the count may be twenty-five per cent. or more of those shown by the gelatine test. It is, of course, not to be expected that there should be any constant relation, or even approximately constant relation, between these two tests. In addition, different waters and different conditions of the same water, even different seasons of the year will show a different relation in the count by the two tests. 
TABLE I.

Comparison of Gelatine and Agar Counts per Cubic Centimetre for VARIOUS Coli Conditions.

Counts shown here are the average for sixteen months

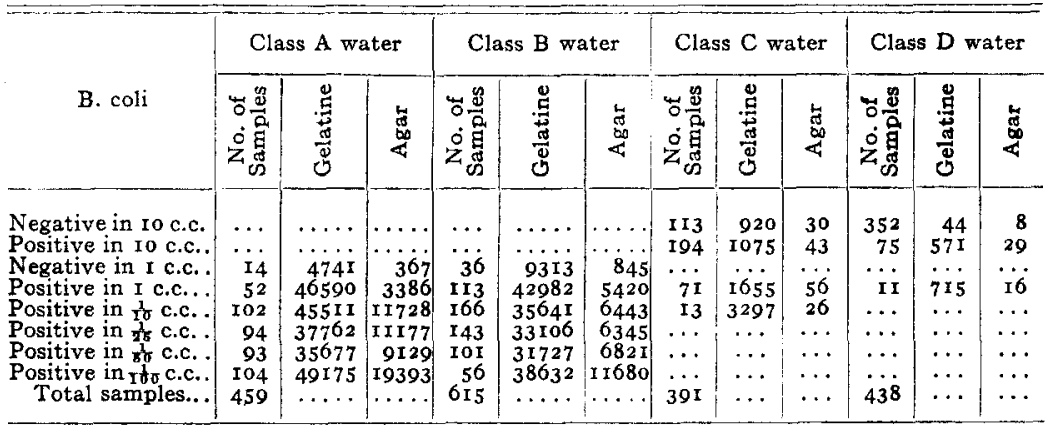

Reference-W. U. C. Baton, Journal Am. W. W. Assn., 1914, Vol. No. I-p. 19.

An instructive series of investigation has recently been made by Dr. Ernst Quantz, at Göttingen, in Germany, and published in the Zeitschrift für Hygiene, I9I4, vol. 78, p. I93. Table II shows the results of this investigation made entirely with various well waters. The well waters are divided by the author into three classes: Group I, as shown in the table, consists of wells which are practically impossible for pollution, and may be considered as safely good well waters. Group II are rather doubtful, and at times might possibly be polluted and at other times be pure. Group III are those classed by the author as particularly bad wells, and pretty nearly certain to be polluted.

TABLE II.

Bacterial Count of Well Waters.

By Dr. Ernst. Quantz-Zeit. f. Hyg.-Vol. 78-Page I93.

\begin{tabular}{|c|c|c|c|c|c|c|}
\hline \multirow{2}{*}{$\begin{array}{c}\text { Bacterial count } \\
\text { per cubic centimetre }\end{array}$} & \multicolumn{3}{|c|}{ Number of examinations } & \multicolumn{3}{|c|}{ Per cent. of examined wells } \\
\hline & Group I & Group II & Group III & $\underset{\text { Grood }}{\text { Group }}$ & $\begin{array}{l}\text { Group II } \\
\text { Doubtful }\end{array}$ & $\underset{\text { Bad }}{\text { Group III }}$ \\
\hline $0-$ & 2 & 0 & 0 & 6 & 0 & 0 \\
\hline II - & 5 & Io & 0 & 16 & 9 & 0 \\
\hline $5 \mathrm{I}-100$ & 3 & IO & 0 & 9 & 9 & 0 \\
\hline $101-200$ & 6 & I 2 & I & Iǵ & Io & 3 \\
\hline $201-500$ & 6 & 22 & 4 & 19 & 19 & I I \\
\hline $501-1000$ & 6 & 18 & 7 & 19 & 15 & 20 \\
\hline $1001-2000$ & 3 & I 8 & 7 & 9 & I 5 & 20 \\
\hline $200 I-5000$ & I & 13 & 5 & 3 & I I & 14 \\
\hline $500 \mathrm{I}-10000$ & o & I I & 3 & o & 9 & 9 \\
\hline $10001 \div 20000$ & o & I & 5 & 0 & I & $r_{4}$ \\
\hline Over-20000 & o & 2 & 3 & 0 & 2 & 9 \\
\hline
\end{tabular}

Vol. CLXXX, No. 1075-3 
In examining these data a very general relationship is shown. Thus, taking Iooo bacteria per cubic centimetre as the limit, we see in Group I that 88 per cent. are under this limit; in Group II, 62 per cent.; and in Group III, 34 per cent. Taking Ioo bacteria as the limit, in Group I, 3 I per cent. are under this limit; in Group II, I8 per cent.; and in Group III, no per cent. This indicates very fairly that better wells, on an average, have a lower bacterial count than the poorer wells. The author's bacterial count was taken on gelatine at $20^{\circ}$ Centigrade.

Individual wells, however, show no such relationship. In some cases good wells show a higher bacterial count than poor wells. Very often the rate of draft on the wells is a bigger factor in the number of bacteria shown than the possibility of pollution. Good wells which have been standing for some time show a very high bacterial count.

The most that can be deduced is that very low counts mean certainly very safe water and very high ones possibly unsafe ones.

As the conclusion of some thirty years of experience, bacterial counts are still taken as showing roughly the variation in the same water. In other words, their chief advantage is found in comparing a water before and after it is filtered. Especially is this true of counts on gelatine at $20^{\circ}$ Centigrade.

When taken alone bacterial counts are not considered ordinarily as a reliable indicator of the safety of the water.

\section{SIGNIFICANCE OF B. COLI AS AN INDICATOR OF POLLUTION.}

After eliminating as a satisfactory indicator of pollution the total count of bacteria which may originate anywhere at all, the next natural step is to restrict our investigation to those particular bacteria which seem likely to originate in the human body. The normal rule seems to be that only human diseases are transmitted to other human beings, and that bacteria, in order to cause infection, must originate in man. Infectious pollution in water supplies arises almost wholly from discharges from the human intestines, and any bacteria which can be assumed to originate in the human intestines would be a fair measure of such human pollution which potentially might be dangerous or infectious. 
Unfortunately, there are no such bacteria which are a positive indicator of human pollution. The nearest thing to it are the coli bacilli. Thus $B$. coli are always found in any discharges from the human intestines. They are also found, however, in the discharges from the intestines of animals, birds, fishes, and on cereals, grains and many other places. They are even found in the air, the dust, and, because of their widespread occurrence, have often been termed "ubiquitous." Because of these conditions it is not a simple matter to say that any water supply which shows the presence of $B$. coli necessarily possesses any specific danger of human pollution or of infection which might at any time have been present. It merely suggests a potential danger in such a water.

This difficulty is made more pronounced by the large number of forms or types in which the $B$. coli appear. The colon bacillus is not a simply definite form of unvarying properties. It represents, rather, a whole class or series of classes of bacteria resembling each other in a certain number of properties and differing in other properties. There is a graded series of bacteria, some of which have in common many qualities, but the extremes of the series have only a small number of things in common. Attempts have been made to divide these coli bacilli into two general classes, one called the typical coli and the other the atypical coli. The typical coli is the one which is most likely to occur in the human intestines, and the atypical coli is that form which is most likely to originate elsewhere.

In 1905 the Committee on Standard Methods of Water Analyses of the American Public Health Association, of which the speaker was a member, drew up a set of standard tests for $B$. coli, designed to distinguish the typical from the atypical form, and to rate only the typical form as $B$. coli.

More modern methods have shown the general tendency to make less difficult and more approximate tests of the occurrence of $B$. coli. They involve the use of the lactose peptone bile "presumptive test" as sufficient to show B. coli and to rate coli or coli gas-forming bacteria by this test. There is a good deal to be said for these simpler, speedier methods now used, even if they are not a positive guide for separating the percentage of $B$. coli which comes from the intestines of man, as distin- 
guished from the bacteria reacting similarly in the laboratory and coming from the intestines of other domestic animals, grains, soils, etc.

The percentage of organisms of the coli group, rated as positive by the presumptive test that would be considered typical $B$. coli by confirmatory tests, varies from at least thirty to ninety per cent., according to various workers testing different waters. Quite possibly in some waters the percentage of $B$. coli of typical forms would be much less than this. It is to be understood that even with this small percentage of typical $B$. coli there is no evidence to show what portion, if any, of the $B$. coli originated in the intestines of man.

In Table III the relations of the $B$. coli result by different methods of testing are given. These figures by Professor Gärtner are taken from Dr. Houston's tests of London water. Three methods of testing are given: the first, the so-called presumptive test, is noted from the gas formation; the second column involves a so-called confirmatory test, as applied by Dr. Houston; and in the third column are given the results of so-called typical tests. Comparing the results given by the presumptive test and by the typical test for one cubic centimetre, we see that for the Thames raw water before storage the typical test showed almost as much coli as the presumptive test, or, in figures, about eighty per cent. as much. In the Lambeth Reservoir, after storage, the typical coli are only about fifty per cent. of those shown by the presumptive test. In the Chelsea Reservoir, after storage, the typical coli are shown to be only about forty per cent. as much as the presumptive coli. In the LaValle Reservoir, after storage, the typical coli are less than twenty per cent. of the presumptive coli.

Generally speaking, the raw water shows a higher percentage of typical coli, and storage waters, which are largely purified by long storage, show a smaller percentage of typical coli. This may be because some, even a large part, of the original coli lose their typical properties in age, as is often claimed to be the case. It may be because the typical coli are less long-lived than the atypical coli. It might also be inferred from this table that the typical coli are better indicators of the water quality than the atypical coli. 
TABLE III.

Relation of B. Coli Results by Different Methods.

By A. Gärtner-Zeitschrift für Hygiene-19 1o, vol. lxvii, p. 55.

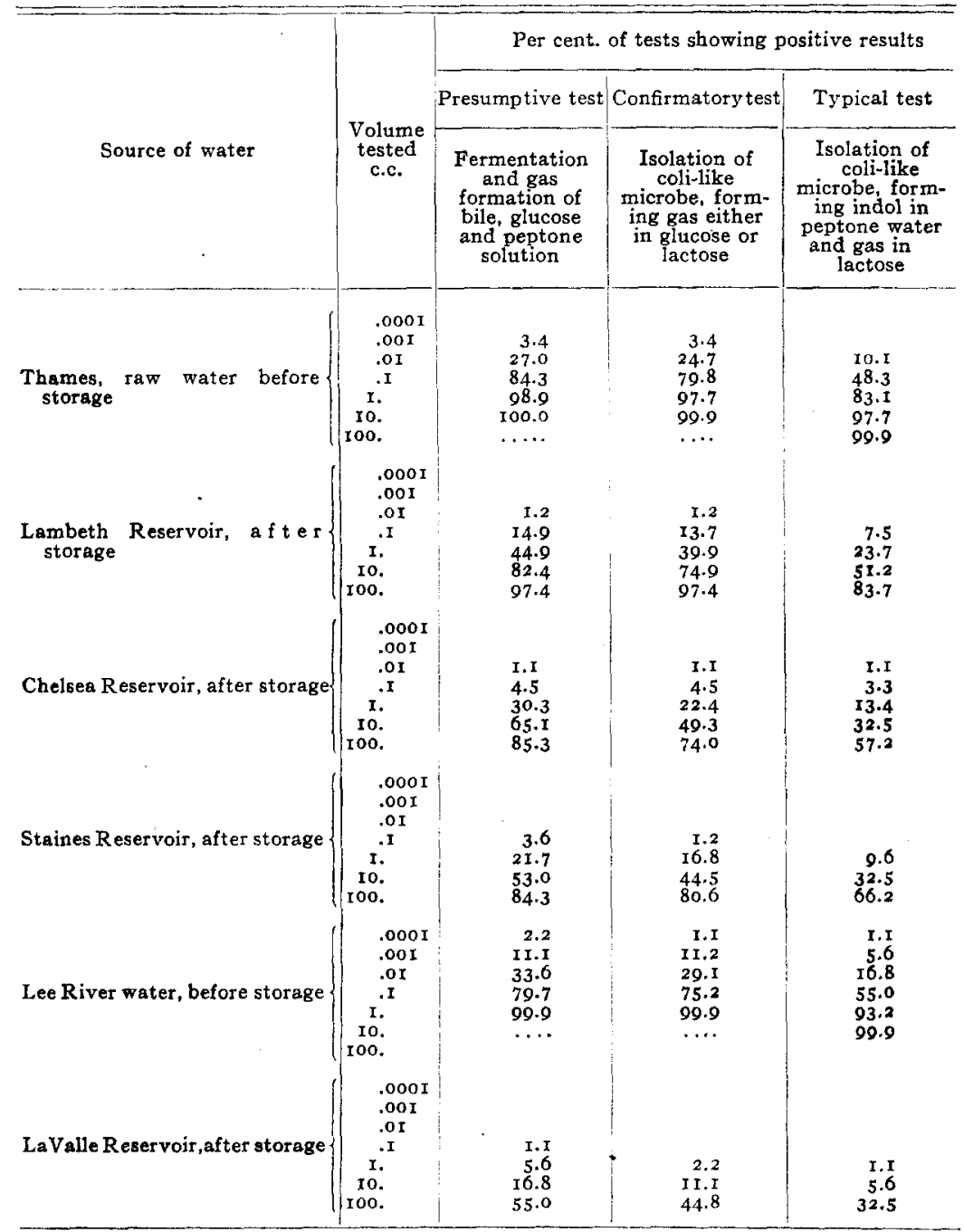

Dr. Houston, in a recent report on the value of storage, points out that storage results in a devitalization of the undesirable bacteria, on account of the water being an unsuitable medium for sustaining their activities. He speaks of this as the "Glagesten" theory in the storage of impure water. 
Coli tests should be used most cautiously in forming an opinion as to the quality of an untreated raw water. Such data should be weighed carefully in connection with a sanitary survey in the light of existing conditions as to the opportunity for pollution.

Realizing the inability to record the source of bacteria producing positive results by the coli tests, particularly as to whether or not they originated in the intestines of man, it is desirable to record what is available by way of information as to the relative prevalence in water of $B$. coli and $B$. typhoid. These results, so far as they have been studied, are quite erratic and unsatisfactory. We will make some mention of several comments, but before doing so it is desired to point out some of the irregularities known to the speaker due to changes in methods of determining $B$. coli, as follows:

In 1898 the speaker had charge of the testing station at the Cincinnati water works. The water was drawn from the intake at the old Front Street pumping station, adjoining the Pennsylvania Railroad train shed. Into the Ohio River above this intake there were emptied the contents of thirty-two city sewers, and six miles above the intake the Ohio also received the flow of the Little Miami River, draining a populous watershed. On the basis of the determinative tests made for $B$. coli then in vogue it was found that sixty per cent. of the samples showed the presence of this organism when one cubic centimetre of the water was tested. (See the speaker's report on Water Purification at Cincinnati, I899, p. 40.)

In 1907 the intake was moved to the present site at California, seven miles above the old intake and one mile above the mouth of the Little Miami River. A marked falling off in the typhoid occurred during the summer of that year, and before the filtration plant was put in service in October of the same year. Since October, I907, the city of Cincinnati has had one of the very lowest typhoid fever death-rates of any American city. By the present method of making the presumptive tests on the untreated Ohio River water at the upper intake now in use a positive result in one cubic centimetre samples is reported in eighty-five or ninety per cent. of the daily samples tested. No increase in population in Pittsburgh or other cities above can possibly explain 
the change in analytical data as compared with those obtained in I 898 .

At New Orleans, during the operation of the water testing station, Mr. R. S. Weston found in I9OI-I902 that out of one hundred tests for $B$. coli he obtained positive results only three times when using from one to three hundred cubic centimetres of water per sample. (See Report on Water Purification Investigation, New Orleans, I903, p. 47.)

By the presumptive method as now practised positive $B$. coli results are obtained in eighty per cent. or more of the one cubic centimetre samples. The present intake is above the city limits, and there has been no striking increase in the population of the cities of the Mississippi valley sewering into this river of great size. The cities of Baton Rouge and Vicksburg have more extensive sewerage than a dozen years ago, but their effect upon pollution at New Orleans can scarcely be measurable.

\section{INTERNATIONAL JOINT COMMISSION STANDARD.}

During the course of this last year an International Joint Commission, consisting of members appointed by the United States and by Canada, have been considering the question of the allowable pollution in international boundary waters. The particular features they were studying were to what extent sewage and other polluting discharges into these boundary waters should be reduced in amount and purified, and to what point these boundary waters might be allowed to be polluted and yet at the same time not occasion, in connection with water purification plants, any menace to public health.

In the course of this investigation this International Joint Commission obtained testimony from a number of sanitary engineers, and formulated a tentative standard of purity for these international boundary waters with respect to the proposition of not overloading water filters.

The problem here was not the one of determining what coli count was permissible for a drinking water. That problem, indeed, could not have readily permitted a general solution in the light of our present knowledge. The conditions of such surface waters as form the international boundary waters are such that safety demands that all of these waters be properly filtered before being used as domestic supplies. The problem, 
then, relates to the extent of pollution permissible and still not make the waters unsafe after reasonable filtration. Giving proper weight to the effective work that can be expected of modern water filters, it is not necessary to specify a very rigid or exatcing standard for the raw water subjected to filtration. An approximate figure, which will reveal a water not extremely polluted, will be satisfactory. On this basis the speaker and his colleagues before the commission fixed a standard for a yearly average by the presumptive method, reasonably checked by confirmatory tests, of testing coli whereby positive results in o.I cubic centimetre samples of water should not occur in more than fifty per cent. of the samples. Averaging this in an arithmetical way, it would mean that there would be not more than about $500 \mathrm{~B}$. coli in each Ioo cubic centimetres of water. It is, of course, to be understood that such arithmetical averaging is not exactly possible, and the results will not correspond in taking one Ioo cubic centimetre sample and in taking one hundred I cubic centimetre samples, or one thousand o. I cubic centimetre samples.

It is not to be assumed, on this basis, that it is impossible to filter properly a water in which the coli content is in excess of the amount here specified. A water may indeed show a much higher coli content and yet be filtered and sterilized after filtration, so that the resulting effluent will be highly satisfactory for all domestic consumption. Nevertheless, there is a good deal of question, as a matter of broad sanitary policy, whether water which is later to be used for drinking should regularly be allowed to become polluted at the intake to a water supply plant in excess of the amount specified. This standard, indeed, is reasonably liberal, and only unusual conditions will make necessary any very expensive purification of sewage wastes in order to keep water for filtration within the limits of this standard.

Table IV shows $B$. coli content in various water supplies. The results shown here are given on the basis of coli content in one cubic centimetre and in nearly all cases the coli bacilli occur only part of the time in the one cubic centimetre test. In the case of the Lawrence, Mass., water taken from the Merrimac River, and of the Albany, N. Y., water taken from the Hudson River, coli are to be found in Ioo per cent. of the tests of the water, and; while the data are not shown in this table, the water roughly approximates to that of the standard tests. Experience has shown, too, that 
these waters, which are the worst permissible by this standard for filtration purposes, are satisfactorily filtered by the Lawrence and Albany filters, and that the resulting effluent is reasonably satisfactory bacterially for drinking purposes.

TABLE IV.

Occurrence of B. Coli in Water Supplies.

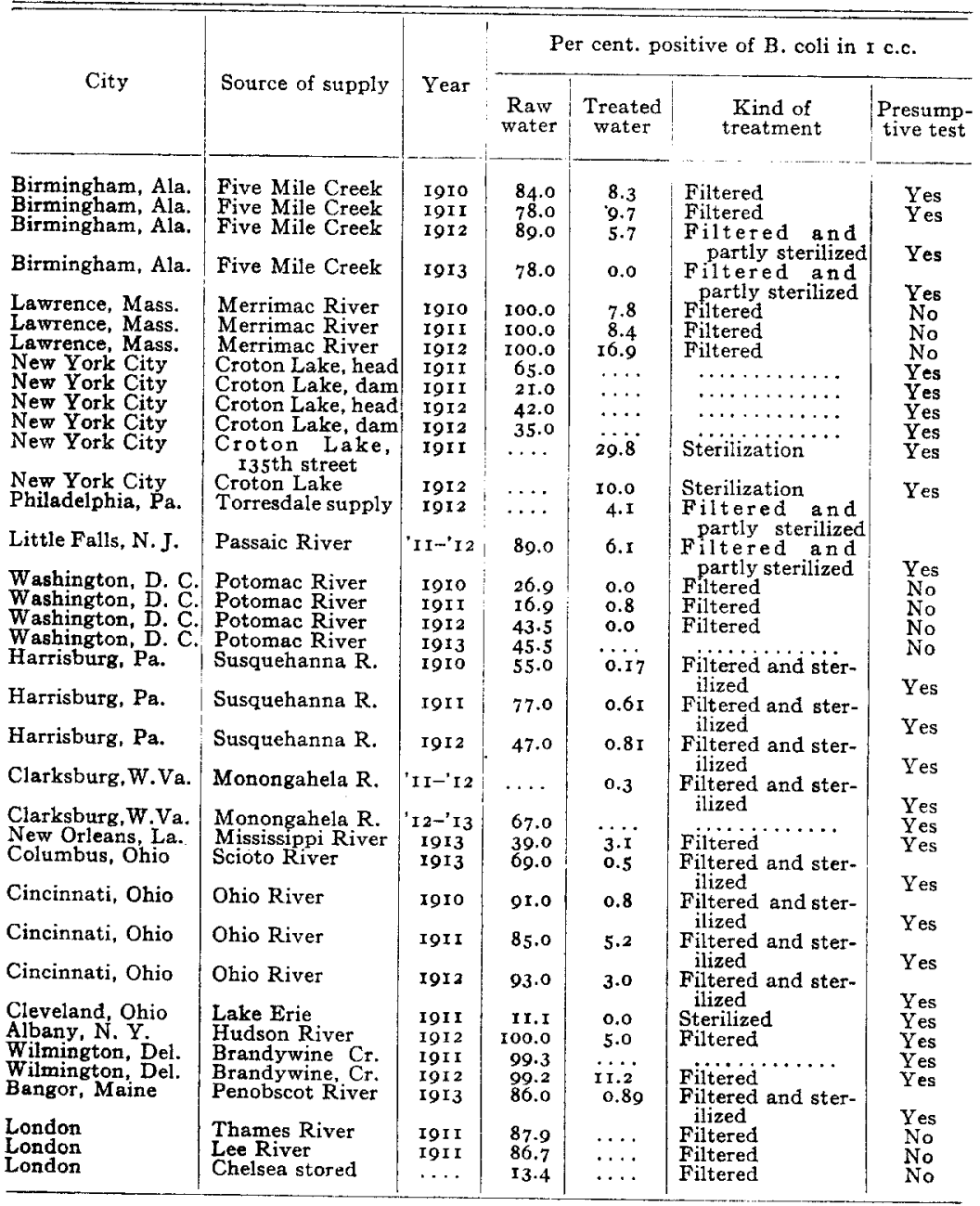

In view of the importance of the pending investigations into the control of the pollution of the boundary waters between the 
United States and Canada, it will not be out of place to include here the guiding principles put before the commission by the sanitary engineers whom they consulted, as follows:

"To the International Joint Commission.

$$
\text { "New York, June 27, I9I4. }
$$

"Gentlemen: The following statements represent the essence of the opinions given by us before your honorable commission at the conference held in New York on May 26 and 27, 1914:

“I. Speaking generally, water supplies taken from streams and lakes which receive the drainage of agricultural and grazing lands, rural communities, and unsewered towns, are unsafe for use without purification, but are safe for use if purified.

" 2. Water supplies taken from streams and lakes into which the sewage of cities and towns is directly discharged are safe for use after purification, provided that the load upon the purifying mechanism is not too great and that a sufficient factor of safety is maintained, and, further, provided that the plant is properly operated.

" 3 . As, in general, the boundary waters in their natural state are relatively clear and contain but little organic matter, the best index of pollution now available for the purpose of ascertaining whether a waterpurification plant is overloaded is the number of $B$. coli per roo cubic centimetres of water expressed as an annual average and determined from a considerable number of confirmatory tests regularly made throughout the year.

“4. While present information does not permit a definite limit of safe loading of a water-purification plant to be established, it is our judgment that this limit is exceeded if the annual average number of $B$. coli in the water delivered to the plant is higher than about 500 per 100 cubic centimetres, or if in o. I cubic centimetre samples of the water $B$. coli is found fifty per cent. of the time. With such a limit the number of $B$. coli would be less than the figure given during a 
part of the year and would be exceeded during some periods.

" 5 . In waterways where some pollution is inevitable and where the ratio of the volume of water to the volume of sewage is so large that no local nuisance can result, it is our judgment that the method of sewage disposal by dilution represents a natural resource, and that the utilization of this resource is justifiable for economic reasons, provided that an unreasonable burden or responsibility is not placed upon any waterpurification plant and that no menace to the public health is occasioned thereby.

" 6 . While realizing that in certain cases the discharge of crude sewage into the boundary waters may be without danger, it is our judgment that effective sanitary administration requires the adoption of the general policy that no untreated sewage from cities or towns shall be discharged into the boundary waters.

" 7 . The nature of the sewage treatment required should vary according to the local conditions, each community being permitted to take advantage of its situation with respect to local conditions and its remoteness from other communities, with the intent that the cost of sewage treatment may be kept reasonably low.

" 8. In general, the simplest allowable method of sewage treatment, such as would be suitable for small communities remote from other communities, should be the removal of the larger suspended solids by screening through a one-fourth-inch mesh or by sedimentation.

" 9. In general, no more elaborate method of sewage treatment should be required than the removal of the suspended solids by fine screening or by sedimentation, or both, followed by chemical disinfection or sterilization of the clarified sewage. Except in the case of some of the smaller streams on the boundary, it is our judgment that such oxidizing processes as intermittent sand filtration, and treatment by sprinkling filters, contact beds, and the like, are unnecessary, inasmuch as ample dilution in the lakes and large streams 
will provide sufficient oxygen for the ultimate destruction of the organic matter.

" 10 . Disinfection or sterilization of the sewage of a community should be required wherever there is danger of the boundary waters being so polluted that the load on any water-purification plant becomes greater than the limit above mentioned.

" II. It is our opinion that, in general, protection of public water supplies is more economically secured by water purification at the intake than by sewage purification at the sewer outlet, but that under some conditions both water purification and sewage treatment may be necessary.

"I2. The bacteriological tests which have been made in large numbers under the direction of the International Joint Commission indicate that in most places the pollution of the boundary waters is such as to be a general menace to the public health should the water be used without purification as sources of public water supply or should they be used for drinking purposes by persons travelling in boats.

"I3. It is our judgment that the drinking water used on vessels traversing boundary waters should not be taken indiscriminately from the waters traversed, unless subjected to adequate purification, but should be obtained preferably from safe sources of supply at the terminals.

"I4. While recognizing that the direct discharge of fecal matter from boats into the boundary waters may often be without danger, yet in the interest of effective sanitary administration it is our judgment that the indiscriminate discharge of unsterilized fecal matter from vessels into the boundary waters should not be permitted.

"Yours respectfully,

"George W. Fuller,

EARle B. Phelps,

George C. Whipple,

W. S. LEA,

T. J. LAFRENIERE." 
Mr. F. A. Dallyn, who was one of the six consulting engineers to advise the commission, presented a minority report, in which he eliminated Paragraphs 5, 7, and Ir, and made a few slight changes in some of the other paragraphs.

BACTERIOLOGICAL STANDARD FOR DRINKING WATER ADOPTED BY THE

TREASURY DEPARTMENT FOR WATER SUPPLIED TO THE PUBLIC BY COMMON CARRIERS IN INTERSTATE COMMERCE.

On October 2I, 19I4, the Treasury Department adopted the standard for interstate carriers for water supplies for public drinking purposes in accordance with the recommendations by a commission appointed by the Secretary of the Treasury, January 22, 19I3. This commission of fifteen sanitarians recommended a standard published in the United States Public Health Reports, vol. 29, No. 45, p. 2960 , dated November 6, I9I4, as follows :

"I. The total number of bacteria developing on standard agar plates incubated twenty-four hours at $37^{\circ}$ Centigrade shall not exceed roo per cubic centimetre: Provided that the estimate shall be made from not less than two plates, showing such numbers and distribution of colonies as to indicate that the estimate is reliable and accurate.

" 2. Not more than one out of five ro cubic centimetre portions of any sample examined shall show the presence of organisms of the bacillus coli group when tested as follows:

" (a) Five Io cubic centimetre portions of each sample tested shall be planted, each in a fermentation tube containing not less than 30 cubic centimetres of lactose peptone broth. These shall be incubated fortyeight hours at $37^{\circ}$ Centigrade and observed to note their formation.

"(b) From each tube showing that more than five per cent. of the coli are in the fermentation tube, plates shall be made after forty-eight hours' incubation upon liquid lactose litmus agar or endo media.

"(c) When plate colonies resembling $B$. coli develop upon either of these plate media within twentyfour hours, a well-isolated characteristic colony shall 